\title{
OPTIMALISASI PEMANFAATAN HUTAN MANGROVE BERBASIS EKOWISATA UNTUK MENINGKATKAN PEREKONOMIAN MASYARAKAT PESISIR KOTA TANJUNGPINANG MENGUNKAN KONSEP LINGKUNGAN BAKAU KITE
}

\section{OPTIMIZATION OF ECOTOURISM-BASED MANGROVE FOREST UTILIZATION TO IMPROVE THE ECONOMY OF COASTAL COMMUNITY IN TANJUNGPINANG CITY USING THE KITE ENVIRONMENTAL CONCEPT}

\author{
Burhan Latif \\ Mahasiswa Fakultas Ekonomi Universitas Maritim Raja Ali Haji (Tanjungpinang) \\ Email : Burhan.latif07@gmail.com
}

\begin{abstract}
ABSTRAK
Tujuan penelitian ini adalah untuk meneliti bagaimanakah kondisi pengelolaan hutan mangrove di KotaTanjungpinang, konsep "Bakau Kite" dapat dikatakan sebagai solusi dalam mengoptimalkan potensi hutan mangrove untuk meningkatkan perekonomian masyarakat pesisir yang berbasiskan ekowisata di Kota Tanjungpinang dan partisipasi masyarakat dalam konsep "Bakau Kite" dengan menggunakan strategi quadruple helix collaboration. Lokasi penelitian di Kota Tanjungpinang, Provinsi Kepulauan Riau pada lokasi pesisir taman bakau dengan konsep bakau kite yang berbasis pada ekowisata. Hasil penelitian menunjukkan bahwa pengelolaan hutan mangrove di wilayah pesisir Kota Tanjungpinang dipandang kurang maksimal dan ditinjau dari sisi manfaat ekonomis dan manfaat ekologis juga kurang diperhatikan, Maka perlu dioptimalkan potensi hutan mangrove di wilayah pesisir Kota Tanjungpinang. Mangrove Kite dapat dijadikan solusi untuk menangani berbagai permasalahan pengelolaan hutan mangrove di wilayah pesisir Kota Tanjungpinang.
\end{abstract}

Kata kunci: Bakau Kite, Ekowisata, Quadruple Helix Collaboration

\begin{abstract}
The purpose of this study was to examine how the conditions of mangrove forest management in Tanjungpinang City, the concept of "Mangrove Kite" can be said as a solution in optimizing the potential of mangrove forests to improve the economy of coastal communities based on ecotourism in Tanjungpinang City and community participation in the concept of "Mangrove Kite" using quadruple helix collaboration strategy. The research location in Tanjungpinang City, Riau Islands Province on the coastal mangrove park location with the concept of mangrove kite based on ecotourism. The results showed that the management of mangrove forests in the coastal area of Tanjungpinang City was considered to be less than optimal and in terms of economic benefits and ecological benefits were also not considered, so the potential of mangrove forests in the coastal area of Tanjungpinang City should be optimized. Kite mangrove can be used as a solution to deal with various problems of mangrove forest management in the coastal area of Tanjungpinang City.
\end{abstract}

Keywords: Kite Mangrove, Ecotourism, Quadruple Helix Collaboration 


\section{PENDAHULUAN}

Indonesia merupakan negara kepulauan terbesar didunia dengan jumlah pulau sebanyak 13.000 pulau (DKN 2016), perairan laut sebesar 5,9 juta $\mathrm{km}^{2}$, perairan darat sebesar 1,9 juta $\mathrm{km}^{2}$, dan panjang garis pantai sebesar $81.000 \mathrm{~km}$. Provinsi Kepulauan Riau merupakan salah satu provinsi maritim yang memiliki panjang garis pantai $2.367,6 \mathrm{~km}$ dengan luas wilayah 251.810 $\mathrm{km}^{2}$. Dimana sekitar $96 \%$ merupakan lautan dan $4 \%$ berupa daratan yang berupa gugusan pulau yang berjumlah 2.408 buah pulau. Selain itu pusat kegiatan Provinsi Kepulauan Riau dapat dijangkau dari Negara Singapura dengan jarak tempuh 1-2 jam perjalanan menggunakan transportasi laut. Provinsi Kepulauan Riau terdiri dari 5 Kabupaten meliputi Kabupaten Bintan, Karimun, Anambas, Natuna, Lingga dan 2 Kota yaitu Kota Batam dan Tanjungpinang (Barenlitbang Provinsi Kepulauan Riau, 2017).

Hutan mangrove merupakan salah satu sumberdaya pesisir dan laut yang sangat bermanfaat dalam mendukung kehidupan penting di wilayah pesisir dan lautan. Fungsi ekologis hutan mangrove diantaranya adalah penyedia makanan bagi biota perairan, tempat pemijahan (spawning ground) bagi bermacam-macam biota, pelindung terhadap abrasi, angin taufan, dan tsunami, penyerab limbah, pencegah intrusi air laut dan sebagainya. Fungsi ekonomis hutan mangrove diantaranya sebagai penyedia kayu bakar, daun-daun untuk obat, bahan bakar, alat penangkap ikan, bahan baku kertas dan sebagainya (Linda, 2013).

Hutan mangrove merupakan suatu ekosistem yang mempunyai peranan sangat penting di tinjau dari sisi ekologis maupun aspek sosial ekonomi. Diantaranya ekosistem ini berfungsi sebagai perlindungan pantai secara alami untuk mengurangi risiko terhadap bahaya abrasi (Majid, et al., 2016). Selain itu juga berfungsi sebagai sumber ikan, udang dan keanekaragaman hayati lainnya, sumber kayu bakar dan kayu bangunan, serta memiliki fungsi konservasi, pendidikan, ekoturisme dan identitas budaya (Setyawan, 2006).

Hutan mangrove merupakan komunitas vegetasi pantai tropis, yang didominasi oleh beberapa spesies pohon mangrove yang mampu tumbuh dan berkembang pada daerah pasang surut pantai berlumpur. Komunitas vegetasi ini umumnya tumbuh pada daerah intertidal dan subtidal yang cukup mendapat aliran air, dan terlindung dari gelombang besar dan arus pasang surut yang kuat. Karena itu hutan mangrove banyak ditemukan di pantai-pantai teluk yang dangkal, estuaria, delta dan daerah pantai yang terlindung (Kenish,1990).

Hutan Mangrove yang ada di Indonesia tersebar di beberapa Provinsi di antaranya Provinsi Kepulauan Riau (Kepri).Kota Tanjungpinang merupakan salah satu Kota yang memiliki potensi mangrove dengan luas 774,25 ha yang terdiri da ri 6 jenis mangrove yaitu Rhizophora sp., Bruguire sp., Sonneratia sp., Avicennia sp. dan Xylocarphus sp, Ceriopps sp(Lestari, 2013).

Linda (2013) menyatakan bahwa Ekosistem mangrove di kawasan pesisir Kota Tanjungpinang tersebar pada empat Kecamatan, yaitu kecamatan Tanjungpinang Kota, Tanjungpinang Barat, Tanjungpinang Timur, dan Bukit Bestari. Berdasarkan pengamatan yang sudah dilakukan di lokasi penelitian sebelumnya memaparkan bahwa komposisi vegetasi mangrove sejati dikawasan pesisir Tanjungpinang dikategorikan homogen. Hal ini sesuai dengan karakteristik mangrove di pulau kecil yang memiliki keragaman jenis yang sangat rendah. Namun penyebaran mangrove di wilayah pesisir Tanjungpinang ditemukan menyebar dikawasan daerah estuari atau muara sungai diantaranya adalah kawasan muara Sungai Ular, muara Sungai Ladi, 
muara Sungai Carang, muara Sungai Tanjung Unggat, muara Sungai Jang, dan muara Sungai Dompak.

Potensi mangrove yang ada di KotaTanjungpinang hingga saat ini masih belumdioptimalkan dengan baik dan masih belum dikelola dengan baik, hal ini berdasarkan observasi yang telah dilakukan, permasalahannya adalah belum adanya sumber daya manusia yang terorganisir secara khusus ditempatkan untuk mengelola hutan mangrove dan minimnya fasilitas pendukung seperti sulitnya akses untuk menuju lokasi dan tidak tersedianya sanitasi.

Jika ditinjau dari aspek sosial masyarakat, pengelolaan hutan mangrove di Kota Tanjungpinang belum melibatkan masyarakat sekitar, padahal dalam aspek pembangunan wilayah pesisir peranan masyarakat sangatlah penting. Kemudian, jika ditinjau dari aspek ekonomi, masih minimnya pengetahuan masyarakat sekitar akan kegunaan mangrove tersebut baik itu potensi dan manfaat mangrove sebagai sumber ekonomi masyarakat yang bisa dijadikan sebagai salah satu indikator pendorong peningkatan ekonomi.

Berdasarkan permasalahan diatas maka diperlukan sebuah solusi terkait dengan meningkatkan perekonomian masyarakat pesisir dan bagaimana mengoptimalisasihutan mangrove dengan konsep "Bakau Kite" yang merupakan upaya untuk mengoptimalisasikan hutan mangrove yang ada di Kota Tanjungpinang dengan berbasis ekowisata/ekoturisme, diharapkan hutan mangrove yang ada di Kota Tanjungpinang dapat dikelola dengan baik sehingga menjadi pusat pertumbuhan ekonomi yang ramah lingkungan.

Berdasarkan latar belakang masalah yang telah diuraikan diatas, maka dapat ditarik suatu rumusan masalah yang akan menjadi pembahasan dalam karya tulis ilmiah ini adalah (1) Bagaimanakah kondisi pengelolaan hutan mangrove di KotaTanjungpinang? (2) Bagaimanakah konsep "Bakau Kite" dapat dikatakan sebagai solusi dalam mengoptimalkan potensi hutan mangrove untuk meningkatkan perekonomian masyarakat pesisir yang berbasiskan ekowisata di Kota Tanjungpinang? dan (3) Bagaimanakah partisipasi masyarakat dalam konsep "Bakau Kite" dengan menggunakan strategi quadruple helix collaboration?

Berdasarkan rumusan penelitian di atas, maka tujuan dari penulisan karya tulis ilmiah ini adalah (1) untuk mengidentifikasi pengelolaan hutan mangrove di Kota Tanjungpinang,ditinjau dari fisik, sosial dan ekonomi, (2) Mendeskripsikan konsep "Bakau Kite" sebagai solusi dalam mengoptimalkan potensi hutan mangrove untuk meningkatkan perekonomian masyarakat pesisir yang berbasiskan ekowisatadi Kota Tanjungpinang dan (3) Mendeskripsikan strategi quadruple helix collaboration dalam menerapkan konsep "Bakau Kite".

\section{LANDASAN TEORI}

\section{Ekosistem Mangrove}

Hutan mangrove adalah tipe hutan yang khas terdapat di sepanjang pantai atau muara sungai yang dipengurahi oleh pasang surut air larut. Mangrove tumbuh pada pantai-pantai yang terlindung atau pantai-pantai yang datar, biasanya di sepanjang sisi pulau yang terlindung dari angin atau di belakang terumbu karang di lepas pantai yang terlindung (Nybakken, 1992).

Ekosistem hutan mangrove bersifat kompleks dan dinamis, namun labil. Dikatakan kompleks karena ekosistemnya di samping dipenuhi oleh vegetasi mangrove, juga merupakan habitat berbagai satwa dan biota perairan. Jenis tanah yang berada di bawahnya termasuk tanah perkembangan muda (saline young soil) yang mempunyai kandungan liat yang tinggi dengan 
nilai kejenuhan basa dan kapasitas tukar kation yang tinggi. Kandungan bahan organik, total hidrogen, dan ammonium termasuk kategori sedang pada bagian yang dekat laut dan tinggi pada bagian arah daratan (Kusmana, 1994).

\section{Fungsi Mangrove}

Suryono(2013), menjelaskan bahwa ekosistem hutan mangrove memberikan banyak manfaat baik secara tidak langsung (non economic value) maupun secara langsung kepada kehidupan manusia (economic vallues). Beberapa fungsi mangrove antara lain adalah: (a) Menumbuhkan Pulau dan Menstabilkan Pantai, (b) Menjernihkan air, (c) Mengawali rantai makanan, (d) Melindungi dan memberi nutrisi dan (e) Manfaat bagi manusia (mulai dari bagian akar, kulit kayu, batang pohon, daun dan bunganya semua dapat dimanfaatkan manusia).

Beberapa kegunaan pohon mangrove yang langsung dapat di rasakan dalam kehidupan sehari-hari antara lain : Tempat Tambat Kapal, Obat-obatan, Pengawet, Pakan dan Makanan. Bahan Mangrove dan Bangunan. Sedangkan menurut Wibisono (2005), secara ekologis ekosistem mangrove mempunyai beberapa fungsi penting bagi wilayah pesisir, diantaranya: (a) Sebagai tempat peralihan dan penghubung antara lingkungan darat dan lingkungan laut, (b) Sebagai penahan erosi pantai karena hempasan ombak dan angin serta sebagai pembentuk daratan baru, (c) Merupakan tempat ideal untuk berpijah (spawning grund) dari berbagai jenis larva udang dan ikan, (d) Sebagai cadangan sumber alam (bahan mentah) untuk dapat diolah menjadi komoditi perdagangan yang bisa menambah kesejahteraan penduduk setempat.

Manfaat sosial ekonomi ekosistem mangrove bagi masyarakat sekitarnya adalah sebagai sumber mata pencaharian dan produksi berbagai jenis hasil hutan dan turunannya, antaralain kayu bakar, arang, bahan bangunan, oat-obatan, minuman, peralatan rumah tangga, bahan baku tekstil dan kulit, madu, lilin dan tempat rekreasi (Hamilton dan Snedaker, 1994 dalam dahuri, 1996).

Menurut FPPB (2009) dalam Baderan (2017), hutan mangrove memiliki fungsi dan manfaat sebagai berikut; Habitat satwa langka; pelindung terhadap bencana alam; pengendapan lumpur; penambah unsur hara; rekreasi dan pariwisata; dan sarana pendidikan dan penelitian.

Menurut Nontji (2005) Mangrove di Indonesia dikenal mempunyai keragaman jenis yang tinggi. Seluruhnya tercatat 89 jenis tumbuhan, 35 jenis diantaranya berupa phon dan selebihnya berupa terna ( 5 jenis), perdu ( 9 jenis), liana (9 jenis), epifit (29 jenis), dan parasit (2 jenis). Beberapa contoh mangrove yang berupa pohon antara lain adalah bakau (Rhizophora), api-api (Avicenia), pedada (Sonneratia), tanjang (Brugueria), nyirih (Xylocarpus), tengar (Ceriops), butabuta (Excocaria). Dari sekian banyak jenis mangrove di Indonesia, jenis api api (Avicennia sp.), bakau (Rhizophora sp.), tancang (Bruguiera sp.) dan pedada (Sonneratia sp.). Merupakan tumbuhan mangrove utama yang paling banyak dijumpai (Nontji, 2005). Jenis-jenis mangrove tersebut adalah kelompok mangrove yang menangkap, menahan endapan dan menstabilkan tanah habitatnya.

\section{Penyebaran dan Zonasi Mangrove}

Pembagian zonasi pertumbuhan sering dibagi berdasarkan daerah penggenangan dan jenis tumbuhan yang tumbuh pada daerah tersebut. Misalnya menurut daerah yang tergenang diklasifikasikan dalam 3 zonasi yaitu : Zona proksimal, Zona midle dan Zona Distal. (1) Zona Proksimal adalah zona yang dekat dengan laut atau zona terdepan. Pada daerah ini biasanya 
ditemukan jenis-jenis Rhizophora apiculata, Rhizophora mucronata, dan Sonneratia alba. (2) Zona Midle adalah zona yang terletak diantara laut dan darat atau zona pertengahan. Biasanya ditemukan jenis-jenis: Sonneratia caseolaris, Rhizophora alba, Bruguiera gymnorrhiza, Avecennia marina, Avecennia officinalis dan Ceriops tagal. (3) Zona Distaladalah zona yang terjauh dari laut atau terbelakang. Pada daerah ini biasa ditemukan jenis-jenis: Heriteria littoralis, Pongamia sp, Xylocarpus sp, Pandanus sp, dan Hibiscus tiliaceus.

Pertumbuhan komunitas vegetasi mangrove secara umum mengikuti suatu pola zonasi. Pola zonasi berkaitan erat dengan faktor lingkungan seperti tpe tanah (lumpur, pasir atau gambut), keterbukaan terhadap hempasan gelombang, salinitas serta pengaruh pasang surut (Dahuri, 2003). Menurut Bengen (2002), hutan mangrove terbagi atas beberapa zonasi yang paling umum, yaitu (1) Daerah yang paling dekat dengan laut dan substrat agak berpasir, sering ditumbuhi oleh Avicennia spp. Pada zona ini, Avicennia spp biasanya berasosiasi denag Sonneratia spp, Yang dominan tumbuh pada substrat lumpur dalam yang kaya bahan organik. (2) Lebih ke arah darat, ekosistem mangrove umumnya didominasi oleh jenis Rhizophora spp. Pada zona ini juga dijumpai Bruguiera dan Xylocarpus, (3) Zona berikutnya didominasi oleh Bruguiera spp, (4) Zona transisi antara hutan mangrove dengan hutan daratan rendah, biasa ditumbuhi oleh Nypa fruticants dan beberapa jenis palem lainnya.

\section{Pariwisata dan Ekowisata}

Menurut Yulianda (2007) dalam Husin (2017), Wisata merupakan suatu bentuk pemanfaatan sumberdaya alam yang mengandalkan jasa alam untuk kepuasan manusia. Kegiatan manusia untuk kepentingan wisata dikenal juga dengan pariwisata. Ekowisata lebih popular dan banyak dipergunakan dibandingkan dengan terjemahan yang seharusnya dari istilah ecotourism. Pengertian tentang ekowisata mengalami perkembangan dari waktu ke waktu. Namun, pada hakekatnya, pengertian ekowisata adalah suatu bentuk wisata yang bertanggung jawab terhadap kelestarian area yang masih alami (natural area), memberikan manfaat secara ekonomi dan mempertahankan keutuhan budaya pada masyarakat setempat. Atas dasar pengertian ini, bentuk ekowisata pada dasarnya merupakan bentuk gerakan konservasi yang dilakukan oleh penduduk dunia. Eco-traveler ini pada hakekatnya konservasionis (Fandeli, 2000).

Menurut Dahuri (2016), alternative pemanfaatan ekosistem mangrove yang paling memungkinkan tanpa merusak ekosistem ini meliputi: penelitian ilmiah (scientific research), pendidikan (education), dan rekreasi terbatas/ ekoturisme (limited recreation/ecoturism). Menurut Muhaerin (2008), Sifat dan karakteristik dari ekowisatawan adalah mempunyai rasa tanggung jawab sosial terhadap daerah wisata yang dikunjunginya.

Wisata menurut Undang-Undang Nomor 9 Tahun 1990 tentang Kepariwistaan didefinisikan sebagai kegiatan perjalanan yang dilakukan secara sukarela dan bersifat sementara, serta perjalanan itu sebagian atau seluruhnya bertujuan untuk menikmati objek dan daya tarik wisata. Sedangkan pariwisata segala sesuatu yang berhubungan dengan wisata, termasuk pengusahaan objek dan daya tarik serta usaha-usaha yang terkait di bidang tersebut. Seringkali pariwisata hanya dilihat dalam bingkai ekonomi, padahal ia merupakan rangkaian dari kekuatan ekonomi, lingkungan dan sosial budaya yang bersifat global. Memang, pariwisata harus bisa menjual. Namun pariwisata dapat juga memberikan manfaat dan menyumbang antara lain kepada pelestarian budaya dan adat istiadat, peningkatan kecerdasan masyarakat, peningkatan 
kesehatan dan kesegaran, terjaganya sumber daya alam dan lingkungan lestari, terpeliharanya peninggalan kuno dan warisan masa lalu.

Pariwisata di Indonesia telah menjadi salah satu industri yang menjadi penyumbang devisa terbesar kedua setelah migas. Pengembangan industri pariwisata pun turut dijadikan sebagai salah satu strategi yang digunakan oleh pemerintah bahkan swasta untuk mempromosikan wilayah tertentu sebagai daerah wisata guna meningkatkan perekonomian dan kesempatan kerja. Upaya pengembangan wisata terkait pula oleh potensi pasar kedepan dimana World Tourism Organization (WTO) memperkirakan bahwa pada tahun 2020 akan terjadi peningkatan sebesar 1.561,1 juta orang dengan pertumbuhan tertinggi di Asia-Pasifik sebesar 6,5\% (Budhyana, 2008).

Ekowisata dapat dilihat dari tiga perspektif, yaitu sebagai (1) produk, (2) pasar, dan (3)pendekatan pengembangan. Sebagai produk, ekowisata merupakan semua atraksi yang berbasis pada sumberdaya alam. Sebagai pasar, ekowisata merupakan perjalanan yang diarahkan pada upaya-upaya pelestarian lingkungan. Akhirnya sebagai pendekatan pengembangan, ekowisata merupakan metode pemanfaatan dan pengelolaan sumberdaya pariwisata secara ramah lingkungan. Di sini kegiatan wisata yang bertanggungjawab terhadap kesejahteraan masyarakat lokal dan pelestarian lingkungan sangat ditekankan dan merupakan ciri khas ekowisata. Pihak yang berperan penting dalam ekowisata bukan hanya wisatawan tetapi juga pelaku wisata lain (tour operatour) yang memfasilitasi wisatawan untuk menunjukkan tanggungjawab tersebut (Damanik, 2006).

Ekowisata mangrove merupakan objek wisata yang berwawasan lingkungan dimanawisata tersebut mengutamakan aspek keindahan yang alami dari hutan mangrove serta fauna yang hidup disekitarnya tanpa harus merusak ekosistem tersebut untuk membuatnya lebih menarik wisatawan, hal ini disebabkan bahwa hutan mangrove mempunyai ciri khas yang khusus dan banyak fauna dan flora yang hidup di sekitarnya.

Ekowisata merupakan mata pencaharian alternatif bagi masyarakat pesisir yang dapatmenambah pendapatan mereka. Selain itu dalam pengelolaan ekowisata dan strategi konservasi hutan mangrove, keterlibatan para stakeholders sangat berperan penting. Proyek ekowisata dapat berhasil jika stakeholders melaksanakan peran mereka dalam pengelolaan ekowisata maupun konservasi hutan mangrove (Satyanarayana, 2012).

\section{Partisipasi Masyakat Dalam Pengelolaan Mangrove}

Menurut Tangkilisan (2005) memberikan pengertian partisipasi sebagai berikut: "Participation is defined as an individual as mental and emosional involvement in a group situasion that encourages him to contribute to group goal and share responsibility for them." Bila diterapkan dalam pembangunan, maka pendapat Keith Davis ini mengandung tiga unsur pokok, yaitU ; (1) Adanya keterlibatan mental dan emosi individu dalam melakukan aktifitas kelompok; (2) Adanya motivasi individu untuk memberikan kontribusi tergerak yang dapat berwujud barang, jasa, buah pikiran, tenaga, dan keterampilan; (3) Timbulnya rasa tanggung jawab dalam diri individu terhadap aktivitas kelompok dalam usaha pencapaian tujuan.

Partisipasi ditempatkan sebagai style of development yang berarti bahwa partisipasi dalam kaitannya dengan proses pembangunan haruslah diartikan sebagai usaha mentranformasikan sistem pembangunan dan bukan sebagai suatu bagian dari usaha system 
mainternance. Sebagaimana dalam Ensiklopedi Administrasi disebutkan bahwa arti dari kata "participation" adalah sesuatu aktifitas untuk membangkitkan perasaan diikutsertakan dalam kegiatan organisasi, atau ikut sertanya bawahan dalam kegitan organisasi. Telah diketahui bahwa partisipasi merupakan suatu bentuk keikutsertaan dimana siapa saja bisa ambil bagian didalamnya termasuk lapisan masyarakat (Tangkilisan, 2005).

Partisipasi juga dapat dilakukan dalam hal pengelolaan termasuk pengelolaan hutan mangrove. Adisasmita (2006), mengemukakan bahwa pendekatan partisipasi masyarakat perlu karena : a) dapat memahami keadaan sosial ekonomi yang sesungguhnya, b) dapat menganalisis sebab akibat dari berbagai kejadian, c) dapat merumuskan solusi untuk mengatasi permasalahan dan kendala yang di hadapi, d) masyarakat memanfaatkan sumberdaya pembangunan, e) dapat mengupayakan peningkatan kemampuan dan kemauan SDM-nya berlandaskan kepercayaan dan keswadayaan.

Munir (2004), mengemukakan bahwa partisipasi masyarakat dapat berjalan dengan aktif apabila masyarakat dibangun atas tiga pilar, yaitu partisipasi, transparansi dan akuntabilitas. Partisipasi bertujuan untuk memberikan penyadaran masyarakat untuk berperan aktif dalam pelestarian sumberdaya alam. Transparansi merupakan keterbukaan penyelenggara pemerintahan dalam memberikan penjelasan ataupun data-data yang dibutuhkan masyarakat. Akuntabilitas berarti dapat dipertanggungjawabkan secara terbuka.

Menurut Utomo (2004), terdapat tiga prinsip pendekatan untuk melibatkan partisipasi masyarakat, yaitu pendekatan pemaksaan untuk partisipasi, pendekatan dengan janji-janji dan pendekatan keterlibatan spotanitas. Pendekatan yang paling ideal dan terbaik adalah pendekatan keterlibatan spontanitas karena didalamnya mengandung aspek kesadaran diri sendiri dan memiliki nilai-nilai semangat untuk berpartisipasi.

\section{Quadruple Helix Collaboration}

Wahyu Lelly (2017), mengajukan konsep quadruple helix sebagai solusi untuk pengembangan inovasi, kreativitas, dan teknologi untuk industri kreatif. kreativitas dan inovasi berhubungan satu sama lain dalam mendukung kinerja inovasi. Saat ini, inovasi dan manfaat penelitian dari berkembang dan hubungan yang tumpang-tindih antara akademisi, pemerintah, dan industri: inovasi adalah proses yang lebih sistematis, dengan aksen pada koordinasi efektif sistem dalam mana keterampilan-keterampilan tinggi disebarkan di wilayah yang berbeda. Dalam sebuah model quadruple helix, Gash (2007) menyatakan pentingnya kebijakan-kebijakan dan praktik-praktik pemerintah, Universitas, dan industri berinteraksi satu sama lain secara cerdik, secara efektif, dan efisien.

Praswati (1195) menemukan bahwa konsep quadruple helix memberikan kontribusi terhadap proses inovasi di industri, universitas, pemerintah, dan, masyarakat sipil, dan bahwa empat sektor akan berinteraksi dengan satu sama lain untuk mempercepat transfer inovasi. Hudani dan Dhewanto (2015) menyatakan bahwa model quadruple helix adalah kerangka konseptual kolaborasi antara universitas, pemerintah, industri, dan masyarakat. Setiap aktor berperan dan sebuah identitas, yaitu, universitas bertindak sebagai peneliti, pemerintah bertindak sebagai pembuat kebijakan-kebijakan, industri bertindak sebagai produsen ekonomi, dan masyarakat bertindak agar sesuai dengan jarak antara mereka tiga pihak (sebagai penghubung atau konektor). Empat tiang organisasi-organisasi dibedakan dari fakta bahwa mereka bekerja untuk meningkatkan daya saing dan inovasi. Pertama, mereka memberikan sebuah forum di 
lembaga terkait yang dapat belajar dari satu sama lain. Kedua, mereka menghubungkan institusi sumber daya pengetahuan dan peluang di luar keuangannya segera mereka. Ketiga, mereka memfasilitasi pengembangan produk baru kolaborasi, layanan, proses, dan kemampuan yang melibatkan universitas-universitas dan pemerintah sebagai tambahan untuk perusahaanperusahaan swasta. Dan akhirnya, dalam beberapa kasus, organisasi non-profit atas nama para pemangku kepentingan sektor swasta mereka.

Etzkowitz (2000) menemukan bahwa pentingnya hubungan antara pemain utama dalam sistem helix telah sebuah era inovasi di mana hubungan antara aktor, yaitu, akademisi, pemerintah, sektor bisnis ditambah masyarakat sipil akan mengakibatkan ide-ide baru dari tingkat tinggi produk-produk yang inovatif dan layanan. Lebih jauh lagi, yang berhubungan dengan teori inovasi quadruple helix teori inovasi, Afonso et al., (1195) menyatakan bahwa sebuah ekonomi inovasi adalah berdasarkan empat helices, iaitu, akademisi, warga, perusahaan, dan pemerintah, dan interaksi mereka. Kami percaya bahwa quadruple helixdikonsephubungan antara keempat aktor dan dampak bersama mereka pada pertumbuhan ekonomi yang layak untuk dapat disampaikan dan menunjukkan secara matematis. Kami mengembangkan sebuah salah satu sektor-model pertumbuhan berbasis gagasan dengan pelengkap antara layanan dan barangbarang menengah, dan produktif pengeluaran publik. Dengan sebuah gagasan-berdasarkan model pertumbuhan, kita dapat mengenali inovasi sebagai sumber utama dari pertumbuhan ekonomi.

\section{METODOLOGI PENELITIAN}

\section{Jenis dan Sumber Data Penelitian}

Jenis penelitian ini adalah deskriptif kualitatif,sedangkan metode penulisan karya tulis ilmiah ini menggunakan metode penulisan gabungan yang mengombinasikan metode penulisan studi pustaka dan metode penulisan hasil observasi.Data yang digunakan dalam karya tulis ilmiah ini adalah data primer dan data sekunder. Data primer diperoleh dari hasil observasi dilapangan secara langsung, sedangkan data sekunder diperoleh dari studi literatur.Data-data yang dipergunakan dalam penyusunan karya tulis ini berasal dari berbagai literatur kepustakaan yang berkaitan dengan permasalahan yang dibahas. Beberapa jenis referensi utama yang digunakan adalah buku, jurnal ilmiah edisi cetak maupun edisi online/internet serta observasi daerah sasaran. Sedangkan lokasi observasi pengambilan data bertempat di wilayah pesisir Kota Tanjungpinang, Kepulauan Riau.Observasi lapangan dilakukan sejak Juli hingga Agustus 2018 di Kota Rebah Tanjungpinang.

\section{Metode Pengumpulan Data}

Metode pengumpulan data yang digunakan adalah metode observasi dengan melakukan pengamatan visual secara langsung di lapangan serta melakukan pencarian data literatur.Menurut Nazir (2003:221), pengumpulan data adalah proses pengadaan data primer untuk keperluan penelitian. Pengumpulan data dapat pula diartikan sebagai cara peneliti menentukan metode setepat-tepatnya untuk memperoleh data. Untuk mengumpulkan data yang diperlukan dalam penelitian ini, Peneliti menggunakan teknik penggumpulan data antara lain : (1) Penelitian kepustakaan (library research), (2) Penelitian lapangan (Field Work Research), penelitian melakukan penelitian secara langsung di lapangan untuk memperoleh data atau melakukan informasi langsung dari responden dengan menggunakan beberapa teknik sebagai berikut : Observasi atau pengamatan secara langsung ke objek penelitian, Wawancara dengan 
cara tanya jawab sambil bertatap muka antara pewawancara dengan responden atau orang yang diwawancarai, dengan atau tanpa menggunakan pedoman. (3) Dokumentasi, yaitu pengumpulan data yang diperoleh dengan cara mencatat data-data, pengumpulan data berdasarkan dokumendokumen, foto-foto dan arsip yang relevan dengan objek yang diteliti(Sugiono 2001:165).

\section{Metode dan Analisis Data}

Analisis data yang dipergunakan dalam penelitian ini adalah analisis secara kualitatif dengan menggunakan model analisis interaktif.Miles dan Kolaborasierman dalam Sugiyono (2001:246), mengemukakan bahwa aktivitas dalam analisis data kualitatif dilakukan secara interaktif dan berlangsung secara terus-menerus sampai tuntas, hingga datanya sudah jenuh. Aktifitas dalam analisis data, yaitu: (a) Reduksi data (data reduction), merupakan bagian dari analisis yang mempertegas, memperpendek, membuat fokus, membuang hal-hal yang tidak penting dan mengatur data sedemikian rupa sehingga dapat membuat kesimpulan akhir, (b) Penyajian data (data display), merupakan suatu rakitan organisasi informasi, deskriptif dalam bentuk narasi yang memungkinkan kesimpulan riset dapat dilakukan. Sajian data harus mengacu pada rumusan masalah sehingga dapat menjawab permasalahan-permasalahan yang diteliti, (c) Penarikan kesimpulan dan verifikasi (conclusion drawing/ verifocation). Dari awal pengumpulan data, peneliti sudah harus memahami arti dari berbagai hal yang ia temui dengan melakukan pencatatan peraturan-peraturan, pola-pola, pernyataan-pernyataan, arahan, sebab akibat dan berbagai proporsi. Kesimpulan perlu diverifikasi agar penelitian yang dilakukan benar dan bisa dipertahankan, (d) Keabsahan data, kredibilitas penelitian kualitatif ini dilakukan melalui trianggulasi. Trianggulasi merupakan teknik penarikan keabsahan data yang memanfaatkan sesuatu yang lain di luar data itu untuk keperluan pengecekan atau pembanding terhadap datadata tersebut (Moleong, 2000:330).

\section{HASIL DAN PEMBAHASAN}

\section{Gambaran Umum Pengelolaan Hutan Mangrove di Wilayah Pesisir Kota Tanjungpinang}

Berdasarkan hasil penelitian yang dilakukan Lestari (2013), telah ditemukan sebanyak tujuh jenis mangrove sejati dikawasan pesisir Kota Tanjungpinang yang terdapat pada empat Kecamatan, yaitu Kecamatan Tanjungpinang Kota, Tanjungpinang Barat, Tanjungpinang Timur, dan Bukit Bestari. Berdasarkan pengamatan pada masing-masing lokasi penelitian menunjukan bahwa komposisi vegetasi mangrove sejati di kawasan pesisir Tanjungpinang dapat dikategorikan homogen. Hal ini sesuai dengan karakteritik mangrove di pulau kecil yang memiliki keragaman jenis yang sangat rendah. Namun penyebaran ekosistem mangrove di wilayah pesisir Tanjungpinang ditemukan menyebar pada kawasan daerah estuari atau muara sungai, diantaranya adalah kawasan muara Sungai Ular, muara Sungai Ladi, muara Sungai Carang, muara Sungai Tanjung unggat, muara Sungai Jang dan muara Sungai Dompak.

Lestari (2013), menyatakan bahwa Berdasarkan hasil pengamatandi lapangan dan pengolahan analisis citra diketahui luas total ekosistem mangrove yang terdapat di kawasan pesisir Kota Tanjungpinang adalah seluas 774,25 hektar. Luas ekosistem mangrove yang ditemukan dalam pengamatan membentuk pola penyebaran yang terdistribusi pada enam kawasan muara sungai, meliputi luas mangrove di kawasan muara sungai Ular dan muara Sungai Ladi yang termasuk pada wilayah Kecamatan Tanjungpinang Kota adalah seluas 323,39 
ha, luas mangrove di kawasan muara Sungai Carang yang merupakan wilayah Kecamatan Tanjungpinang Timur adalah seluas 55,63 ha, luas mangrove di kawasan pesisir Tanjung unggat yang termasuk ke dalam wilayah kecamatan Tanjungpinang barat adalah seluas27,38 ha, dan luas mangrove di kawasanmuara sungai Jang dan muara sungai Dompak yang termasuk ke dalam wilayah administrasi Kecamatan Bukit Bestari adalah seluas 367,85 ha dapat diketahui bahwa pada masing-masing kawasan muara sungai, luas mangrove yang paling besar ditemukan di Muara Sungai Dompak wilayah kecamatan Bukit Bestari dengan luas mangrove 305,53 ha, ini di karenakan kondisi mangrove di kawasan tersebutrelatif masih baik dan belum banyak mengalami konversi lahan mangrove menjadi fungsi lain. Sedangkan luas mangrove yang paling sedikit terdapat pada Kecamatan Tanjungpinang Barat yaitu kawasan pesisir Tanjung unggat yaitu hanya seluas 27,38 ha. Hal ini disebabkan di kawasan tersebut sudah banyak kegiatan konversi lahan mangrove menjadi kawasan pertambangan, permukiman dan kegiatan perkotaan lainnya.

Mangrovedi Kota Tanjungpinang sudah mulai terancam seiring dengan perkembangan yang terjadi di Kota tersebut, terancamnya mangrovedi Kota Tanjungpinang disebabkan karena pengkaplingan kawasan mangroveoleh warga yang beralasan karena dianggap sebagai kawasan tidak bertuan yang bisa dimanfaatkan. Kondisi seperti ini juga dipicu oleh era keterbukaan dengan gerbong reformasi, selain dengan masalah pengkaplingan, terancamnya mangrove di Kota Tanjungpinang disebabkan dengan penimbunan kawasan hutan mangrove untuk kepentingan lain yang dikarenakan Kota Tanjungpinang merupakan daerah yang cukup menjanjikan bagi pencari kerja, kawasan mangrovesering dikorbankan dan ditimbun untuk dijadikan komplek perumahan maupun tempat usaha. Dengan melihat kondisi ini apabila tidak diantisipasi akan menimbulkan dampak bagi daerah rendah disekitarnya yaitu kebanjiran, karena kawasan mangrovemerupakan salah satu daerah resapan air, selain itu penyebab terancamnya mangrove yang sangatmerugikan adalah illegal logging untuk diselundupkan ke Malaysia maupun Singapura, selain merugikan Negara dan Pemerintah Daerah, penebang liar tersebut tidak menggunakan sistem syllvikultur atau tebang pilih sesuai teknis kehutanan, tidak melaksanakan anakan yang tinggal serta tidak melakukan penanaman untuk areal yang miskin anakan mangrove(Fitriady, 2014)

\section{Konsep Bakau Kite.}

Melihat potensi hutan mangrove di wilayah pesisir Kota Tanjungpinang yang tentunya dalam upaya meningkatkan perekonomian masyarakat pesisir kota Tanjungpinang tersebut memiliki peluang yang cukup besar untuk dioptimalisasikan. Hutan mangrove itu sendiri memiliki manfaat dari segi ekologis maupun dari segi ekonomis. Hutan mangrove merupakan salah satu sumberdaya pesisir dan laut yang sangat bermanfaat dalam mendukung kehidupan penting di wilayah pesisir dan lautan. Fungsi ekologis hutan mangrove diantaranya adalah penyedia makanan bagi biota perairan, tempat pemijahan (spawning ground) bagi bermacam-macam biota, pelindung terhadap abrasi, angin taufan, dan tsunami, penyerap limbah, pencegah intrusi air laut dan sebagainya. Fungsi ekonomis hutan mangrove diantaranya sebagai penyedia kayu bakar, daun-daun untuk obat, bahan bakar, alat penangkap ikan, bahan baku kertas dan sebagainya.

Untuk itu dibuatlah "Bakau Kite" sebagai solusi dalam menangani berbagai permasalahan hutan mangrove yang ada di wilayah pesisir Kota Tanjungpinang untuk 
meningkatkan perekonomian masyarakat pesisir dengan melibatkan masyarakat pesisir itu sendiri sebagai pemeran utama dan mengedepankan upaya pengentasan kemiskinan, penyerapan tenaga kerja dan juga melestarikan lingkungan.Dalam konsep ini, "Bakau Kite" dijadikan objek wisata yang sekaligus dijadikan sebagai tempat pengolahan ataupun pemanfaatan hutan mangrove untuk dijadikan produk yang bernilai ekonomis, serta konservasi mangrove. Dikatakan sebagai objek wisata yaitu tempat para wisatawan dalam negeri ataupun wisatawan mancanegara berkunjung dengan melihat kekayaan alam yang indah di wilayah pesisir Kota Tanjungpinang khususnya hutan mangrove.Sebagai pusat pemanfaatan dan pengolahan mangrove yaitu adanya kegiatan produksi berupa pemanfaatan dan pegolahan mangrove menjadi makanan, minuman dan kerajinan tangan yang tentunya memiliki nilai ekonomis.Dan pusat konservasi yaitu disediakannya bibit mangrove, alal-alat dan Standard Operational Procedure (SOP) penanaman mangrove bagi pengunjung untuk melakukan kegiatan konservasi yang bisa menyelamatkan dan menumbuhkan kesadaran akan pentingnya konservasi mangrove.

\section{Quadruple Helix Collaboration sebagai strategi dalam menjalankan konsep Bakau Kite.}

Mengutip pendapat Wahyu Lelly (2017) pada bab sebelumnya, yang mengajukan konsep quadruple helix sebagai solusi untuk pengembangan inovasi, kreativitas, dan teknologi untuk industri kreatif. kreativitas dan inovasi berhubungan satu sama lain dalam mendukung kinerja inovasi.konsep quadruple helix memberikan kontribusi terhadap proses inovasi di industri, universitas, pemerintah, dan, masyarakat sipil, dan bahwa empat sektor akan berinteraksi dengan satu sama lain untuk mempercepat transfer inovasi. Kebijakan-kebijakan dan praktikpraktik pemerintah, Universitas, dan industri berinteraksi satu sama lain secara cerdik, secara efektif, dan efisien merupakan hal terpenting dalam konsep quadruple helix collaboration. Pemetaan konsep strategi quadruple helix collaboration digambarkan dalam dalam gambar 1 . dibawah ini.

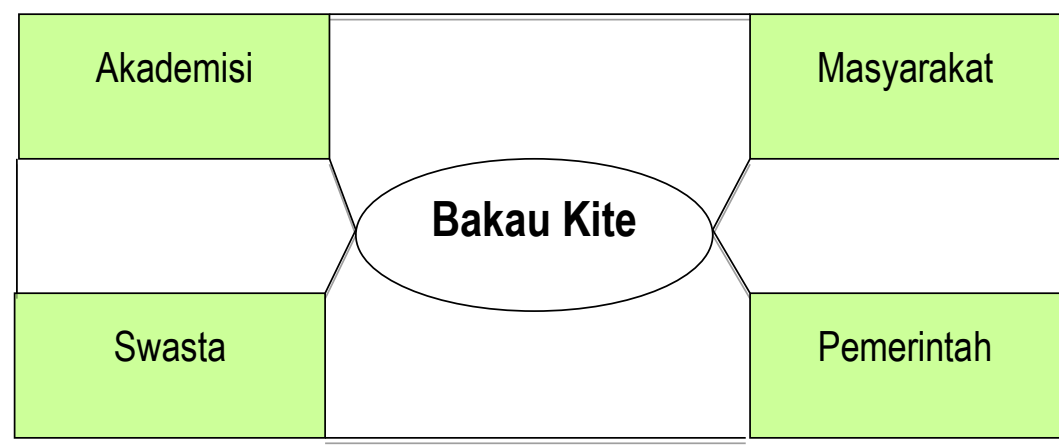

Gambar 1. Konsep Bakau Kite

Strategi quadruple helix collaboration merupakan sinergi dan penyatuan empat pihak yang terdiri dari kalangan akademisi, swasta, masyarakat dan pemerintah. Strategi ini merupakan 
formulasi fungsional yang digunakan dalam mendukung sebuah konsep ataupun inovasi "bakau kite". Kerjasama yang dilakukan oleh empat sektor tersebut haruslah seimbang serta diimplementasikan secara efektif dan efisien. Dalam hal ini pihak akademisi diharapkan memiliki sumberdaya, ilmu pengetahuan dan teknologi yang menfokuskan diri untuk menghasilkan berbagai temuan dan inovasi yang aplikatif serta dapat melakukan riset ataupun penelitian yang dapat menjadi acuan terbaru dalam memetakan konsep dan inovasi pembangunan.Kalangan bisnis melakukan kapitalisasi atau pemodal yang memberikan keuntungan ekonomi dan kemanfaatan bagi masyarakat.Masyarakat diharapkan menjadi pemeran utama dalam berpartisipasi terhadap kepariwisataan yang bersifat ekonomis serta dapat turut ikut andil dalam berusaha membangun ekonomi dengan cara menjalankan konsep bakau kitepada bagian kegiatan usaha guna untuk meningkatkan pendapat rumah tangga masyarakat itu sendiri. Sedangkan pemerintah menjamin dan menjaga serta mendukung hubungan satu dengan lainnya dengan regulasi kondusif.Penulis percaya bahwa quadruple helix collaboration merupakan strategi yang sangat tepat dalam menjalankan kelangsungan konsep dan inovasi bakau kite.

\section{KESIMPULAN DAN REKOMENDASI KEBIJAKAN}

\section{Kesimpulan}

Melihat potensi hutan mangrove di wilayah pesisir Kota Tanjungpinang dengan luas sebesar 774,25 hektar dengan membentuk pola penyebaran yang terdistribusi pada enam kawasan muara sungai, meliputi muara sungai Ular, muara sungai Ladi, muara sungai Carang, Tanjung unggat, muara sungai Jang dan muara sungai Dompak. Dapat disimpulkan bahwasanya ekosistem mangrove terluas terdapat di muara sungai Dompak dengan 305,53 ha, dan luas yang paling sedikit terdapat pada pesisir Tanjung Unggat dengan 27,38 ha.

Dengan melihat potensi ekosistem mangrove yang tentunya memiliki peluang untuk dioptimalkan, maka kemudian penulis menawarkan sebuah konsep yang memadukan ekowisata yang memperhatikan kelestarian vegetasi mangrove, pengolahan/pemanfaatan serta konservasi mangrove. Sebagaidearah ekowisata yang memperhatikan kelestarian hutan mangrove itu sendiri dan dijadikan tempat pengolahan/pemanfaatan hutan mangrove yang dijadikan sebagai alternatif untuk meningkatkan perekonomian masyarakat pesisir Kota Tanjungpinang dengan melibatkan masyarakat, akademisi, pemerintah dan swasta yang disebut dengan strategi quadruple helix collaboration dalam pengimplementasiannya.

\section{Rekomendasi Kebijakan}

Diharapkan perhatian khusus pemerintah daerah dalam hal pengembangan dan pengelolaan kawasan pesisir Kota Tanjungpinang, sehingga apa yang direncanakan dapat berjalan sesuai harapan dan juga perlu dilaksanakannya program rehabilitasi mangrove di setiap kawasan pesisir Kota Tanjungpinang, agar dapat memaksimalkan manfaat hutan mangrove.Diharapkan "Bakau Kite" ini dapat segera di realisasikan untuk mengoptimalkan potensi hutan mangrove yang ada di Kota Tanjungpinang sebagai pusat pemanfaatan dan pengembangan hutan mangrove yang melibatkan masyarakat salah satunya didalam indikator strategi quadruple helix collaboration.Perlu adanya kerjasama yang baik dari seluruh elemen 
masyarakat mulai dari pemerintah, swasta, akademisi hingga masyarakat sekitar guna terealisasinya "Bakau Kite" ini.

\section{DAFTAR PUSTAKA}

Adisasmita, R. 2006. Membangun Desa Partisipatif. Yogyakarta. Graha IImu

Ansell, C. \& Gash, A. 2007. Collaborative Governance in Theoryand Practice. Journal of Public Administration Research and Theory18: 543-571.

B. Flippo. 2000. Manajemen sumber daya manusia.Jakarta Cherrington, David J. 1995. The management of human resources. New Jersey:Prentice Hall Inc.

Baderan, D.W.K. 2017. Hutan Mangrove dan Pemanfaatannya.Yogyakrta: Deepublish

Barenlitbang Provinsi Kepulauan Riau, 2017. Potensi Kepri. https://barenlitbangkepri.com/potensi-kepri/ [8 Agustus 2018]

Bengen D.G. 2002.Ekosistem dan Sumberdaya Alam Pesisir.Pusat Kajian Sumberdaya Pesisir dan Lautan.Fakultas Perikanan dan IImu Kelautan.Institut Pertanian Bogor. Bogor.

Budhyana, I. (2008). Kebijakan Disbudpar dalam Mengembangkan Kawasan Wisata diJawa Barat. Makalah pada Seminar Pembangunan Kepariwisataan di Jawa Barat, Bandung: UPI.

Dahuri R, J. Rais, S.P.Ginting dan M.J Sitepu. 1996. Pengelolaan Sumberdaya Pesisir dan Lautan Secara Terpadu.Jakarta: P.T. Saptodadi.

Dahuri, R. 2003. Keanekaragaman Hayati Laut. Jakarta: PT Gramedia Pustaka Utama

Dahuri, R. Cetakan ketiga 2016.Menuju Indonesia sebagai Poros Maritim Dunia.Bogor: Radar Bahari.

Damanik, Janianton \& Weber, Helmut F. 2006. Perencanaan Ekowisata: Dari Teori keAplikasi. Pusat Studi Pariwisata (PUSPAR) UGM dan ANDI Press. Yogyakarta.

[DKN] Dewan Ketahan Negara. 2016. Jumlah pulau di Indonesia. https:dkn.go.id/ruangopini/9/jumlah-pulau-di-indonesia.html [5 Agustus 2018]

Etzkowitz, H. and Leydesdorff, L. (2000). The dynamics of innovation: from National Systems and "Mode 2" toa Triple Helix of university-industry-government relations", Research Policy, 29, 109-123.

Husin, Z. Ismail, K \& Susiana. 2017. Kajian kesesuaian mangrove kawasan pesisir Dompak Tanjungpinang Kepulauan Riau. Laporan.

Kenish, M.J. 1990. Ekologi of Estuaries. Volume II: Biological Aspects. CRC Press Inc. Boca Raton Flodida.

Kusmana, 1994. Prosiding seminar V: ekosistem mangrove, jember, 3-6 agustus 1994: 247-265. Kontribusi MAB Indonesia No. 72-LIPI. Jakarta

Lestari, F. 2014. Komposisi jenis dan Sebaran Ekosistem Mangrove di kawasan Pesisir Kota Tanjungpinang Kepulauan Riau. Jurnal Dinamika Maritim IV (1) : 68-75. ISSN: 2086-8049.

Linda W.Z \& Ulfa. F. 2013. Valuasi ekonomi hutan mangrove di pulau Dompak Kota Tanjungpinang Provinsi Kepulauan Riau. Dinamika Maritim Volume IV (I) 45-52. ISSN: 2086-8049.

Majid, I., Al muhdar,M.H.I., Rochman, F., Syamsuri, I.2016. Konservasi Hutan Mangrove di Pesisir Pantai Kota Ternate Terintegrasi Kurikulum Sekolah. Jurnal Bioedukasi 4 (2) : 488496.

Moleong, L. 2000. Metodologi Penelitian Sosial. Bandung: Roda Karya. 
Munir, D.A. 2004. Ada Tiga Pilar Dalam Menumbuhkan Partisipasi Masyarakat. Majalah Gema Desa Hutan, Edisi XIV

Nontji, A. 2005. Laut Nusantara. Jakarta: Djambatan.

Nybakken, J. W. 1992. Biologi Laut Suatu Tinjauan Ekologis. Jakarta: PT Gramedia

Satyanarayana, B., et, al. 2012. A Socio-Ecological Assessment Aiming at ImprovedForest

Resource Management and Sustainable Ecotourism Development in the Mangroves of Tanbi Wetland National Park, The Gambia, West Africa. AMBIO 2012,41:513-526.

Setyawan, A.W. 2006. The direct exploitation in the mangrove ecosystem in Central Java and the land use in its surrounding; degradation and its restoration effort, Biodiversitas 7 (3): 282291.

Sugiyono. 2013. Metode Penelitian Pendidikan Pendekatan Kuantitatif, Kualitatif, dan R\&D. Bandung: Alfabeta.

Tangkilisan, Nogi Hessel. 2005. Manajemen Publik. PT. Gramedia Widiasarana Indonesia : Jakarta.

Utomo, P. 2004. Partisipasi Tidak Sekedar Pelibatan Dalam Kegiatan. Majalah Gema Desa Hutan, Edisi XIV

Wahyu Lelly, Sri. 2017. The Quadruple Helix Model: Enhancing Innovative Performance Of Indonesian Creative Industry. International Journal of Scientific and Technology Research. 6 (11): 91-92.

Wibisono, M. S. 2005. Pengantar ilmu kelautan. PT Gramedia Widiasarana Indonesia, Jakarta. 